A Publication of the Materials Research Society

Volume XX, Number 6 ISSN : 0883-7694 CODEN: MRSBEA

\section{ORGANIC THIN FILMS}

18 Organic Thin Films: An Overview

D.G. Whitten, T. Kajiyama, and

T. Kunitake, Guest Editors

22 Chemistry of Self-Assembling Bilayers and Related Molecular Layers

T. Kunitake

26 Structural Evaluation and Molecular Control of Vacuum-Evaporated Organic Thin Films K. Matsushige

32 Novel Concepts of the Aggregation Structure of Organic Monolayers on the Surface of Water T. Kajiyama

39 Supramolecular Assemblies of Chromophores in LB Films and Related Media

H. Chen, C.W. Farahat, M.S. Farahat, H.C. Geiger, U.W. Leinhos, K. Liang, X. Song, T.L. Penner, A. UIman, J. Perlstein, K-Y. Law, and D.G. Whitten

46 Surface Absorption of Monolayers

A. Ulman

52 The Quartz-CrystalMicrobalance Study of Protein Binding on Lipid Monolayers at the Air-Water Interface Y. Okahata, Y. Ebara, and T. Sato

\section{MRS NEWS}

60 Kuech, Renschler, and Tsai to Chair 1996 MRS Spring Meeting

\section{JMR ABSTRACTS}

63 Abstracts for August 1995 Joumal of Materials Research

\section{DEPARTMENTS}

4 Research/Researchers

14 Washington News

15 Public Affairs Forum

16 Editor's Choice

16 Advertisers in This issue

17 Resources

57 University Chapter News

58 Conference Report

61 Historical Note

70 Library

71 Classified

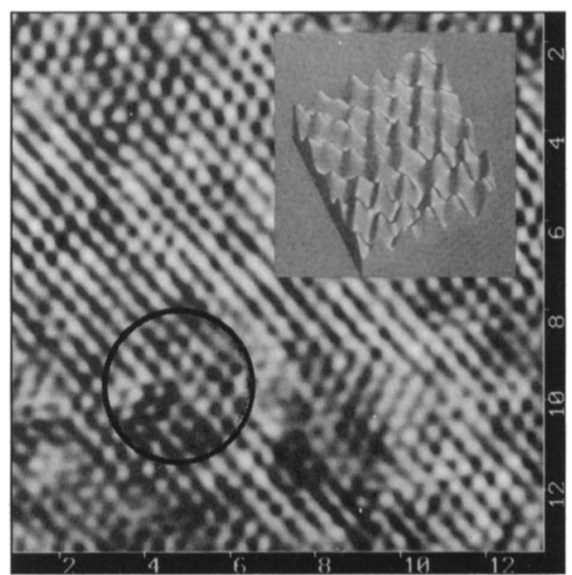

ON THE COVER: Atomic force microscopy image of a lignoceric acid monolayer over a scan area of $13.5 \times 13.5 \mathrm{~nm}^{2}$. The brighter portions in the picture, arranged in a hexagonal array, are individual methyl groups with (10) spacing of $0.43 \mathrm{~nm}$. The inset (a $3 \times 3 \mathrm{~nm}^{2}$ scan area) corresponds to the marked circle and apparently exhibits a discontinuous molecular array in the crystal lattice. A typical edge dislocation can be observed in the center portion of the image, in which an additional molecular array is inserted between two molecular arrays coming down. For more information, please see "Novel Concepts of the Aggregation Structure of Organic Monolayers on the Surface of Water" on page 32. 
The Materials Research Society (MRS), a nonprofit scientific association founded in 1973, promotes interdisciplinary goal-oriented basic research on materials of technological importance. Membership in the Society includes nearly 11,600 scientists, engineers, and research managers from industrial, government, and university research laboratories in the United States and nearly 50 countries.

TheSociety's interdisciplinary approach differs from that of single-discipline professional societies because it promotes information exchange across the many technical fields touching materials development. MRS sponsors two major international annual meetings encompassing approximately 50 topical symposia, and also sponsors numerous single-topic scientific meetings. The Society recognizes professional and technical excellence, conducts short courses, and fosters technical interaction in local geographic regions through Sections and University Chapters.

MRS participates in the international arena of materials research through the International Union of Materials Research Societies (IUMRS). MRS is a member of the Federation of Materials Societies and is an affiliate of the American Institute of Physics.

MRS publishes symposium proceedings, MRS Bulletin, Journal of Materials Research, and other publications related to current research activities. 12 times a year by the Materials Research Society,9800 McKnight Road, Pittsburgh, PA 15237. Application to mail at second class rates has been approved at Pittsburgh, PA and at additional mailing offices. POSTMASTER: Send address changes to MRS Bulletin in care of the Materials Research Society, at the address listed; phone (412) 367-3003; fax (412) 367-4373. Printed in the U.S.A.

Additional copies of articles in the MRS fee can be paid to the Materials Research Society through the Copyright Clearance Center, Inc., 27 Congress Street, Salem, MA 01970.

Membership in MRSis $\$ 75$ annually for regular members, $\$ 25$ for students and retired members. Dues include an allocation of $\$ 29$ ( $\$ 17$ for students and retirees) to a subscription to MRS Bulletin. Individual member subscriptions are for personal use only. Non-member subscription rates are $\$ 120$ for one calendar year (12 issues) within the U.S.A. and $\$ 175$ elsewhere. Single copies may be purchased for $\$ 16$ each. Send subscription orders to Subscription Department, Materials Research Society, 9800 McKnight Road, Pittsburgh, PA 15237.

MRS Bulletin is included in Current Contents $\%$ Engineering, Computing, and Technology; Current Contents $\%$ Physical, Chemical, and Earth Sciences, the SciSearch ${ }^{*}$ online database, Research Alert', and the Materials Science Citation Index". Back volumes of MRS Bulletin are available in $16 \mathrm{~mm}$ microfilm, $35 \mathrm{~mm}$ microfilm, or $105 \mathrm{~mm}$ microfiche through University Microfilms Inc., 300 North Zeeb Road, Ann Arbor, Michigan 48106.

\section{Materials Research Society 9800 McKnight Road \\ Pittsburgh, PA 15237-6006}

Tel. (412) 367-3003; Fax (412) 367-4373

Editorial Office • 9800 McKnight Road • Pittsburgh, PA 15237-6006

Tel. (412) 367-3003; fax (412) 367-4373

Publisher

G.A. Oare

Editor

E.L. Fleischer

Managing Editor

J. Meiksin

Assistant Editor

L.R. Gallagher

Copy Editors

J. Guenther and L.A. Krysinski

Art Director

C. Love

Design/Production

T. Aiello and S. Franklin
Editorial Assistants

M.M. Costello and J. Dininny

Advertising

M.E. Kaufold

Circulation

S.E. Krasa

Guest Editors

T. Kajiyama, T. Kunitake,

and D.G. Whitten

Special Contributors

I. Amato, M. Current, M. Freedhoff, and $\mathrm{E}$. Pennisi

Special Consultant

M. Goodway
Associate Editor-Europe

I.W. Boyd

University College London

Dept. of Electronic and

Electrical Engineering

Torrington Place

London WCI E7 JE, U.K

Tel. 71-387-7050 ext. 3956 or 7304

Book Review Editor

C.J. McHargue

University of Tennessee

Knoxville, Tennessee

MRS Office of Public Affairs

555 13th Street NW, Suite 900 East Washington, DC 20004

Tel. (202) 383-8809, Fax (202) 383-8877

CHAIR-EDITORIAL BOARDS

E.N. Kaufmann • Argonne National Laboratory • Argonne, Illinois, USA

MRS Bulletin (ISSN: 0883-7694) is published Bulletin may be made at $\$ 2.50$ per article. This

\section{INTERNATIONAL ADVISORY BOARD}

M. Balkanski

University of Pierre and Marie Curie

Paris, France

R.G. Elliman

Australian National University

Canberra, Australia

S. Hsu

Chung Shan Institute of Science

and Technology, Retired

Taiwan, China

TECHNICAL EDITORIAL BOARD
L.C. Ianniello

U.S. Department of Energy, Retired

Washington, DC, USA

H-D. Li

National Science Foundation-China

Beijing, China

P. Rama Rao

Ministry of Science and

Technology

New Delhi, India
R. Roy

The Pennsylvania State University

University Park, Pennsylvania, USA

T. Sugano

Toyo University

Tokyo, Japan

D.L. Weaire

Dublin, Ireland
University of Dublin
F.Y. Fradin

Argonne National Laboratory

Argonne, Illinois, USA

B.M. León

Universidad de Vigo

Vigo, Spain

G.L. Liedl

Purdue University

West Lafayette, Indiana, USA
J.C. Bravman

Stanford University

Stanford, California, USA

C.W. Draper

AT\&T Engineering Research Center

Princeton, New Jersey, USA

E. Fogarassy

Centre de Recherches Nucléaires

Strasbourg, France

\section{S. Namba}

Osaka University

Osaka, Japan

A.D. Romig Jr.

Sandia National Laboratories

Albuquerque, New Mexico, USA

J. Soares

Universidade de Lisboa

Lisboa, Portugal

K.C. Taylor

General Motors R\&D Center

Warren, Michigan, USA

\section{MRS BULLETIN PUBLICATIONS SUBCOMMITTEE}

M. Nastasi, Chair

Los Alamos National Laboratory

Los Alamos, New Mexico

R.C. Ewing

University of New Mexico

Albuquerque, New Mexico
A.J. Hurd

Sandia National Laboratories

Albuquerque, New Mexico

M. Libera

Stevens Institute of Technology

Hoboken, New Jersey
F. Shapiro

Drexel University

Philadelphia, Pennsylvania

C.W. White

Oak Ridge National Laboratory

Oak Ridge, Tennessee

\section{MRS EXECUTIVE GOMMITTEE}

President Secretary Immediate Past President

$\begin{array}{ll}\text { President } & \text { Secretary } \\ \text { J.M. Phillips } & \text { C.C. Koch }\end{array}$

J.M. Phillips

C.C. Koch

First Vice President and President-Elect

North Carolina State University

C.V. Thompson

Treasurer

A.K. Hays

Massachusetts Institute of Technology Sandia National Laboratories

J.C. Bravman

Stanford University

Executive Director

Materials Research Society

Second Vice President

R. Hull

University of Virginia
President

M. Doyama

Nishi-Tokyo University

Tokyo, Japan
Vice President

R.C. Ewing

University of New Mexico

Albuquerque, New Mexico

USA
INTERNATIONAL UNION OF MATERIALS RESEARCH SOCIETIES

IUMRS ADHERING BODIES

$\begin{array}{lll}\text { Secretary } & \text { Treasurer } & \text { Immediate Past President } \\ \text { G-C.Chi } & \text { L-C. Lee } & \text { P. Siffert } \\ \text { National Central University } & \text { ITRI } & \text { Centre de Recherches Nucléaires } \\ \text { Chung-Li, Taiwan } & \text { Taiwan } & \text { Strasbourg, France }\end{array}$

General Secretary

R.P.H. Chang

Northwestern University

Evanston, Illinois

USA

Australian Materials Research Society (A-MRS)

J.S. Williams, Austalian National University

Chinese Materials Research Society (C-MRS)

$\mathrm{H}-\mathrm{D}$. Li, National Science Foundation-China

European Materials Research Society (E-MRS)

P.A. Glasow, Siemens AG

Chung-Li, Taiwan

Strasbourg, France
Materials Research Society of India (MRS-I)

P. Rama Rao, Technology Bhavan

Materials Research Society of Japan (MRS-J)

T. Takagi, Ion Engineering Research Institute Corp.

Materials Research Society of Korea (MRS-Korea)

M.C. Chon, Chon International $\mathrm{Co}$. Inc.
Materials Research Society of Russia (MRS-Russia)

I.V. Gorynin, Prometey Institute

Materials Research Society of Taiwan (MRS-T)

L-C. Lee, Industrial Technology Research Institute

Mexican Materials Research Society (Mexican-MRS)

M.J. Yacamán, Instituto de Fisica UNAM 


\section{New horizons in}

\section{materials research}

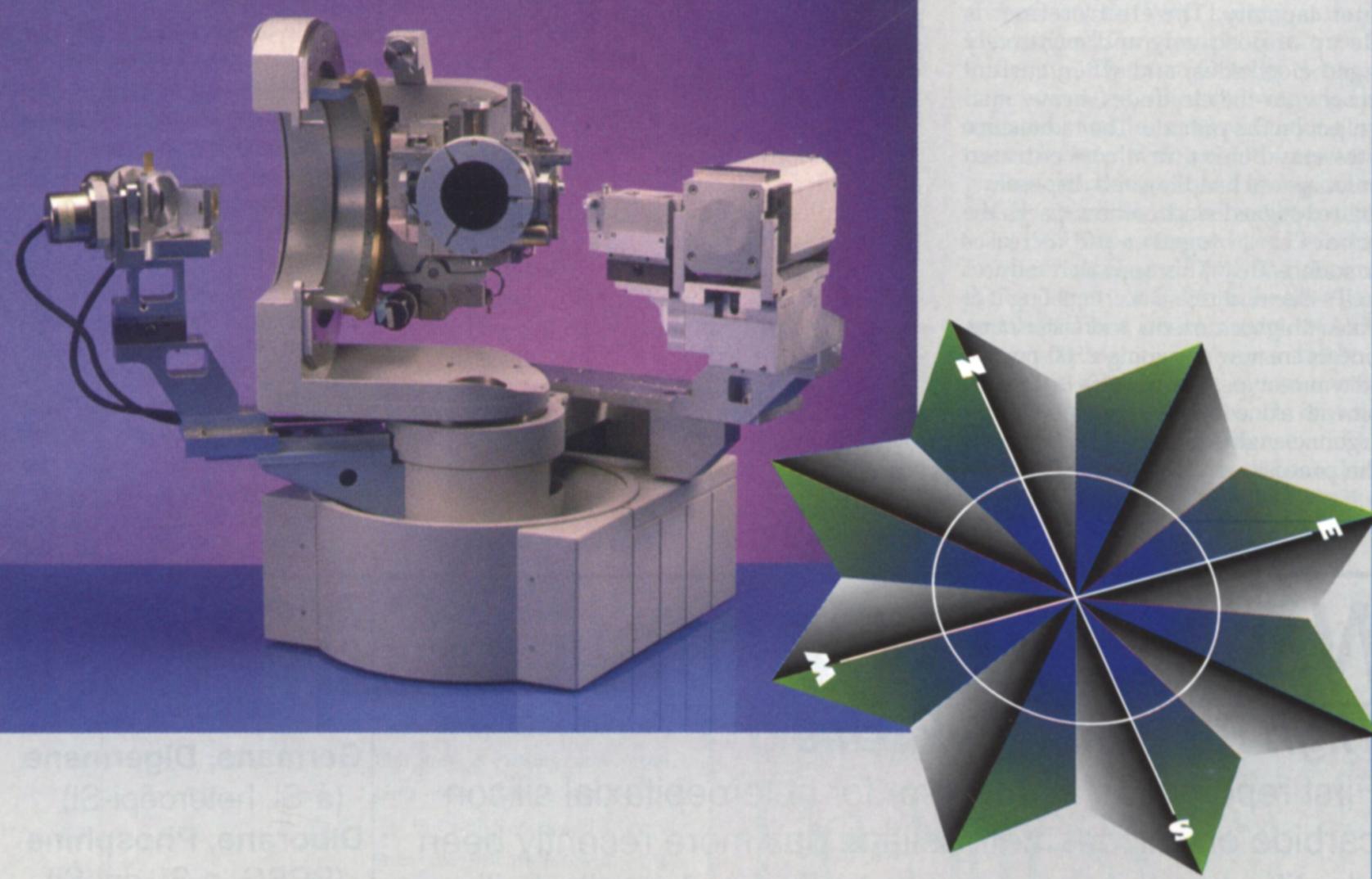

The brand new X'Pert-Materials Research Diffractometers from

Philips offer you the easiest access to direct solutions in materials research.

Optimum performance, versatility and immediate results in:
- High resolution
- Texture
- Thin film
- Stress
- Reflectometry
- Phase

\section{Seeing is believing}

Please ask for a free demonstration disk
Philips Analytical X-Ray BV Lelyweg 1, 7602 EA Almelo, The Netherlands.

Tel. +31 (546) 839430 .

Fax +31 (546) 839598 .

Philips Electronic Instruments Company 85 McKee Drive, Mahwah, NJ 07430, USA.

Tel. +1 (201) 5296246 .

Fax +1 (201) 5295084 . 